\title{
ANTIBACTERIAL EFFECT OF XANTHORRHIZOL (CURCUMA XANTHORRHIZA ROXB.) AGAINST THE BIOFILM OF FUSOBACTERIUM NUCLEATUM
}

\author{
MAIDA FITRI ${ }^{1}$, KAMIZAR NAZAR ${ }^{2 *}$, RATNA MEIDYAWATI $^{2}$, REZA AZMI $^{1}$ \\ ${ }^{1}$ Conservative Dentistry Residency Program, Faculty of Dentistry, Universitas Indonesia, Indonesia. ${ }^{2}$ Department Conservative Dentistry, \\ Faculty of Dentistry, Universitas Indonesia, Indonesia. Email: Kamizar_kz@yahoo.com
}

Received: 25 September 2019, Revised and Accepted: 29 June 2020

\section{ABSTRACT}

Objective: Endodontic infections are treated with a root canal; one of the stages involves using an irrigation solution to eliminate microorganisms. Sodium hypochlorite $(\mathrm{NaOCl})$ is an irrigation solution used to eliminate Fusobacterium nucleatum, the common cause of primary endodontic infections. However, this material is synthetic and can cause side effects and inflammation of the periapical tissues. Thus, an irrigation solution, such as xanthorrhizol, which is made of natural ingredients, is required. However, xanthorrhizol's antibacterial effect against $F$. nucleatum has never been assessed. Thus, this study aimed to analyze the effect of xanthorrhizol, derived from Curcuma xanthorrhiza Roxb., against F. nucleatum ATCC 25586 biofilm.

Methods: The methylthiazol tetrazolium (MTT) assay test and colony count test were performed to assess $F$. nucleatum eradication after exposure to xanthorrhizol at various concentrations $(0.5 \%, 0.75 \%, 1 \%, 1.25 \%$, and $1.5 \%)$ and $2.5 \% \mathrm{NaOCl}$, which was used as positive control.

Results: Significant differences were observed in terms of cell viability after treatment with xanthorrhizol at concentrations of $1.25 \%$ versus $0.5 \%$, $0.75 \%$, and $1 \%$. The MTT assay test was used to evaluate cell viability in the biofilm and cell metabolism activities. Results showed no significant differences in terms of efficacy between xanthorrhizol at concentrations of $1.25 \%$ and $1.5 \%$, which are considered effective against $F$. nucleatum, and $2.5 \% \mathrm{NaOCl}(\mathrm{p}>0.05)$

Conclusion: The effect of xanthorrhizol at concentrations of $1.25 \%$ and $1.5 \%$ against $F$. nucleatum is similar to that of $2.5 \% \mathrm{NaOCl}$.

Keywords: Xanthorrhizol, Fusobacterium nucleatum, Sodium hypochlorite, Antibacterials, Biofilm.

(c) 2020 The Authors. Published by Innovare Academic Sciences Pvt Ltd. This is an open access article under the CC BY license (http://creativecommons. org/licenses/by/4. 0/) DOI: http://dx.doi.org/10.22159/ijap.2020.v12s2.PP-06

\section{INTRODUCTION}

Microorganisms in the root canal cause endodontic infections [1]. In general, various types of anaerobic bacteria dominate these infections. Lee et al. (2017) have found that approximately $70.3 \%$ and $29.7 \%$ of bacteria in the root canal are anaerobes and aerobes, respectively. Some types of anaerobic bacteria, which are found in endodontic infections, are gram-negative bacteria, including Fusobacterium nucleatum [2]. Siqueira and Rocas (2011) have used reverse-capture checkerboard DNA-DNA hybridization, and the proportion of $F$. nucleatum bacteria was the highest in symptomatic primary endodontic infections (acute apical abscess; $>10^{6} \mathrm{CFU}$ ). Furthermore, it was the fourth highest bacteria population (as many as $10^{6} \mathrm{CFU}$ ) in cases of asymptomatic primary endodontic infections [3]. Pereira et al. (2017) conducted a study using real-time polymerase chain reaction on the teeth with periapical lesions caused by endodontic failure. Their results showed that, in the area around the tip of the root and periapical tissue with chronic lesion, the percentage $(71.3 \%)$ of $F$. nucleatum was the highest, followed by Dialister pneumosintes (58.3\%) and Tannerella forsythia (48.3\%) [4].

F. nucleatum is an obligate gram-negative anaerobic bacterium, and it has a role as a bridge bacterium between early and late bacterial colonization d biofilm formation. These bacteria's outer and inner membranes are limited by the periplasmic space, which contains the peptidoglycan layer. The inner layer membranes comprise the phospholipid bilayer; the amount between phospholipids and proteins was balanced. The outer membranes serve as a molecular sieve; they have an asymmetrical shape and are composed of phospholipids, lipopolysaccharide, lipoproteins, and proteins. The lipopolysaccharide (LPS) components on F. nucleatum include lipid $\mathrm{A}$ and $\mathrm{O}$-antigen polysaccharide, which is a lipopolysaccharide endotoxin [5,6]. LPS can trigger the synthesis of interleukin 1 alpha and tumor necrosis factor-alpha (TNF- $\alpha$ ), which is released from macrophages and is involved in bone resorption in apical periodontitis [7].

Virulence factors make $F$. nucleatum pathogenic to human body tissues [8]. In addition to oral diseases, the bacteria can cause several systematic diseases [9], based on the capability to co-aggregate with other bacterial species in co-infections. Previous research has shown that $F$. nucleatum can co-aggregate with Enterococcus faecalis. The interaction between these two bacteria has contributed significantly to the occurrence of endodontic lesions [10]. Reis et al. (2016) have conducted in vivo studies on mice, and results showed that exposure to $F$. nucleatum biofilms and both $F$. nucleatum and E. faecalis could induce higher expressions of RANKL, TNF- $\alpha$, and interferon-gamma than exposure to E. faecalis biofilm on the $10^{\text {th }}$ day [11].F. nucleatum may be found in oral cavity infections, such as post-treatment endodontic diseases, acute dental abscess, endodontic flare-ups, and periodontal disease $[4,9]$.

Successful endodontic treatment is based on eliminating bacteria from the root canal through disinfection [12]. This procedure can be performed through instrumentation, canal irrigation, and root canal treatment. The root canal system has a complex anatomical shape. Thus, the instrumentation process was less effective in eliminating microorganisms. Thus, irrigation during instrumentation is required. Unlike mechanical instrumentation, this method may result in a complete debridement and can reach the entire root canal system [13].

$\mathrm{NaOCl}$ is the most common irrigation solution used in endodontic treatment. It has an antibacterial effect and can dissolve necrotic 
tissues, organic dentin components, and biofilms. A higher $\mathrm{NaOCl}$ concentration can increase these irrigation materials' toxicity levels if it comes in contact with the periapical tissues, and it can trigger an allergic reaction [14]. Considering that the irrigation materials currently used have toxic properties, alternative irrigation solutions that are made from natural materials and have antibacterial properties must be considered.

Indonesia is an agricultural country, with farming areas and large plantations for medicinal plants. Turmeric (Curcuma xanthorrhiza Roxb.) is one of the country's natural commodities [15]. It ranked ninth among the best herbal plants that have numerous benefits, including its use in herbal medicine, which is an in-demand commodity. The use of Turmeric (Curcuma xanthorrhiza Roxb.) for the manufacture of traditional herbal medicine is very large in number, reaching 3000 dry tons per year [16]. Moreover, turmeric is an herbal medicine component because it has a metabolite content, which contains bioactive compounds produced through a secondary metabolite, which is effective against pathogens, or it plays a role in environmental adaptation. Thus, it used as a component in medicines for humans [17]. Turmeric has hepatoprotective, antioxidant, antiinflammatory, anticariogenic, antimutagenic, immunomodulatory, anti-aging, antibacterial, antifungal, insecticidal, and anticoagulant properties [18].

Turmeric (Curcuma xanthorrhiza Roxb.) has three functions, which are as follows: Starch, curcumin, and essential oils [18]. Essential oils contain xanthorrhizol, which is a major active compound, with a concentration of $64.38 \%$ [17]. The active compound of xanthorrhizol helps disrupt oral bacteria's biofilm formation [19]. Rukayadi and Hwang (2006) have reported that this active substance has a strong antibacterial effect against Streptococcus mutans [20]. Prijatmoko (2018) has shown that essential oil, extracted from Curcuma xanthorrhiza Roxb., can inhibit F. nucleatum and E. faecalis growth, and the most effective concentration is $100 \%$ [21]. According to Kim et al. (2008), xanthorrhizol at a concentration of $1 \%$ is considered effective against $S$. mutans biofilms [19].

This study aimed to analyze the antibacterial effect of xanthorrhizol, an active substance in turmeric (Curcuma xanthorrhiza Roxb.), against $F$. nucleatum ATCC 25586 biofilms.

\section{MATERIALS AND METHODS}

We conducted an in vitro laboratory study. The independent variable was the antibacterial effect of xanthorrhizol at various concentrations $(0.5 \%, 0.75 \%, 1 \%, 1.25 \%$, and $1.5 \%)$ and $2.5 \%$ sodium hypochlorite $(\mathrm{NaOCl})$. Meanwhile, the dependent variable was the test material's antibacterial effect against Fusobacterium nucleatum ATCC 25586 biofilm.

In this study, 95\% xanthorrhizol had been isolated from turmeric (Curcuma xanthorrhiza Roxb.) extract purchased from Javaplant. This solution was obtained by extracting ginger through percolation, evaporation, separation, and purification. The percolation process produces Curcuma simplicia. The resulting extract is still in the form of ethanol, which contains xanthorrhizol and curcumin, called percolates. Then, the percolate was concentrated through evaporation with a rotary evaporator, until it became a liquid concentrate. Next, xanthorrhizol and curcumin were separated, and this process involved mixing the liquid concentrate with hexane 1:1. Curcumin remained soluble in ethanol and xanthorrhizol in hexane. Curcumin was below and xanthorrhizol was above the solution. The next process was purifying xanthorrhizol. In total, $10 \mathrm{~mL}$ of xanthorrhizol was used for each concentration. The solution was diluted with dimethyl sulfoxide (DMSO) to obtain a concentration of $0.5 \%, 0.75 \%, 1 \%, 1.25 \%$, and $1.5 \%$.

In total, $100 \mu \mathrm{L}$ of $F$. nucleatum ATCC 25586 was mixed into 990 $\mu \mathrm{L}$ of Brain Heart Infusion (BHI) broth (Oxoid, the UK) and was incubated in an anaerobe condition $\left(\mathrm{N}_{2}, 80 \% ; \mathrm{H}_{2}, 10 \%\right.$; and $\mathrm{CO}_{2}$,
$10 \%$ ) for $72 \mathrm{~h}$ at a temperature of $37^{\circ} \mathrm{C}$. To assess the biofilm count, the suspension was diluted into $1 \times 10^{6} \mathrm{CFU} / \mathrm{mL}$. The biofilms were incubated and transferred to 96 -well plates by adding $100 \mu \mathrm{L}$ of F. nucleatum suspension, and the mixture was added to every well plate. Furthermore, the suspension was incubated at $37^{\circ} \mathrm{C}$ for $72 \mathrm{~h}$. When biofilms had formed in each well, $100 \mathrm{~mL}$ of various xanthorrhizol concentrations were added. In the positive control, $100 \mathrm{~mL}$ of $2.5 \%$ $\mathrm{NaOCl}$ was added to each well. In the negative control, the F. nucleatum suspension had no intervention. Then, the biofilm was incubated with the test substance for $15 \mathrm{~min}$ at a temperature of $37^{\circ} \mathrm{C}$. The control blank comprises the BHI broth medium and xanthorrhizol solution at various concentrations. This process was duplicated for each xanthorrhizol concentration and positive control. The methylthiazol tetrazolium (MTT) test was then performed, and the first stage involved rinsing each well plate with $100 \mathrm{~mL}$ of phosphate-buffered solution (PBS) solution, and manufacturing MTT solution with a concentration of $5 \mathrm{mg} / \mathrm{mL}$. Moreover, $10 \mathrm{~mL}$ of MTT solution was added to each well containing the test material and was incubated for $3 \mathrm{~h}$ at a temperature of $37^{\circ} \mathrm{C}$. Then, $100 \mathrm{~mL}$ of acidified isopropanol was added to each well. The well plate was placed on a shaker for $1 \mathrm{~h}$. The optical density value was assessed using a microplate reader with a wavelength of $490 \mathrm{~nm}$. Biofilm eradication was expressed as a percentage of formula eradication [22,23].

$$
\text { Eradication }(\%)=\left(1-\left(\begin{array}{c}
\text { ODsample }- \\
\frac{\text { ODblancsample }}{\text { ODnegativecontrol }-} \\
\text { ODblancnegativecontrol }
\end{array}\right) \times 100 \%\right)
$$

Next, the antibacterial effect of xanthorrhizol at concentrations of $0.5 \%, 0.75 \%, 1 \%, 1.25 \%$, and $1.5 \%$ and $2.5 \% \mathrm{NaOCl}$ against F. nucleatum ATCC 25586 was assessed using the colony count method. In total, $100 \mu \mathrm{l}$ of the biofilms of $F$. nucleatum ATCC 25586 from stock cultures were taken, placed on a well plate with a predetermined design, and then incubated for $72 \mathrm{~h}$ at a temperature of $37^{\circ} \mathrm{C}$. Then, the well plate was rinsed to remove planktonic materials. The formed biofilm was exposed to the test material according to the specified plate design.

The samples, which have been treated and remained at the bottom of the plate, were scraped, placed in a PBS solution, and mixed using a vortexer for $20 \mathrm{~s}$; then, $1 \mu \mathrm{l}$ of the solution was cultured in agar medium. Each sample was dropped and rubbed on the BHI agar medium and then incubated at $37^{\circ} \mathrm{C}$ for $72 \mathrm{~h}$. The antibacterial effect of all the test materials was evaluated by calculating the colonies. F. nucleatum bacteria, which are still alive after exposure to the test material and formed a colony in the BHI preparation, were then calculated manually. The lower the number of colonies formed, the lower the CFU/mL value, and the higher the antibacterial effect.

Data were collected, and the Statistical Package for the Social Sciences software, version 24, was used in all analyses. Statistical analysis was performed to test data normality. If the data had a normal distribution, parametric tests were conducted using oneway analysis of variance. Meanwhile, if the data distribution were abnormal, the Kruskal-Wallis test was used. A p $<0.05$ was considered statistically significant.

\section{RESULTS AND DISCUSSION}

The antibacterial effect of xanthorrhizol at various concentrations $(0.5 \%, 0.75 \%, 1 \%, 1.25 \%$, and $1.5 \%)$ was analyzed using the MTT assay. Table 1 shows the eradication value of xanthorrhizol at various concentrations and $2.5 \% \mathrm{NaOCl}$ against the biofilms of $F$. nucleatum ATCC 25586.

Table 1 shows there were significant differences between xanthorrhizol at various concentrations and $2.5 \% \mathrm{NaOCl}$ in the eradication percentage (\%) of the F. nucleatum ATCC 25586 biofilm. 
This study examined the antibacterial effect of xanthorrhizol at various concentrations against $F$. nucleatum biofilm. Biofilm formation is one of the most important virulence factors of $F$. nucleatum due to a higher resistance ability to host defense or antibacterial agents compared to F. nucleatum's planktonic forms. Under biofilm conditions, F. nucleatum can be more resistant to oxidative stress and host response [6]. As shown in Table 1, xanthorrhizol has an antibacterial effect against the biofilm of F. nucleatum. This study is similar to that of Kim (2008), which showed that xanthorrhizol has an antibacterial effect against $S$. mutans biofilms. The post hoc Mann-Whitney U test was used to assess these differences.

As shown in Table 2, there were significant differences in the eradication value against the biofilm of $F$. nucleatum between xanthorrhizol at concentrations of $1.25 \%, 0.5 \%, 0.75 \%$, and $1 \%$. However, there was no significant difference between xanthorrhizol at a concentration of $1.5 \%$ and $2.5 \% \mathrm{NaOCl}$. Moreover, the eradication value between xanthorrhizol at all concentrations, except $0.5 \%$, and $2.5 \% \mathrm{NaOCl}$, did not differ significantly.

On this study, the optimal xanthorrhizol concentration was $1.25 \%$ (Table 2). Meanwhile, Kim's study (2008), the optimal concentration was $1 \%$. The difference in optimal concentration is attributed to the different bacteria species that were tested [19] Yue et al. (2015) showed that xanthorrhizol has an antibacterial effect against E. faecalis ATCC 29212 biofilm. The optimal concentration in this study was different because a concentration of $1 \%$ on Yue's study (2015) was used for xanthorrhizol and it was dissolved with 30\% ethanol, 1\% DMSO, and $100 \mathrm{mg} / \mathrm{mL}$ of sodium methyl cocoyl taurate [24].
Table 3 represents the total count of $F$. nucleatum biofilms on the well plate. There was a significant difference in the total count of $F$. nucleatum biofilms after exposure to xanthorrhizol at concentrations of $0.5 \%$, $0.75 \%, 1 \%, 1.25 \%$, and $1.5 \%$ and $2.5 \% \mathrm{NaOCl}$.

Significant differences were observed in the $F$. nucleatum biofilm colony count between xanthorrhizol at various concentrations and 2.5\% NaOCl. As shown in Table 4, the post hoc Mann-Whitney U test was used to assess the difference in colony count between the various concentrations of xanthorrhizol.

There was a significant difference in the number of colony count between xanthorrhizol at a concentration of $1 \%$ and at $1.25 \%$ and $1.5 \%$ and $2.5 \% \mathrm{NaOCl}$. Meanwhile, there were no significant differences between xanthorrhizol at concentrations of $1.25 \%$ and $1.5 \%$ and $2.5 \%$ $\mathrm{NaOCl}$

This study, similar to Prijatmoko's study (2018), has shown that the active compound in essential oils made from turmeric (Curcuma xanthorrhiza Roxb.) can inhibit F. nucleatum growth [21].

F. nucleatum has been used as ATCC 25586, which is one of F. nucleatum's characteristics in the root canal [1]. Future studies must use samples of clinical isolates to identify the actual strain of microorganisms in the root canal.

$\mathrm{NaOCl}$ is an irrigation solution that is most used in endodontic treatments. Al-Madi et al. (2019) have shown that $2.5 \% \mathrm{NaOCl}$ has antibacterial effects against $F$. nucleatum. This solution has an

Table 1: Eradication value (\%) between xanthorrhizol at various concentrations and $2.5 \% \mathrm{NaOCl}$ against the biofilms of $F$. nucleatum ATCC 25586

\begin{tabular}{|c|c|c|c|c|c|}
\hline \multirow[t]{2}{*}{ Treatment group (concentrations) } & \multirow[t]{2}{*}{$\mathbf{n}$} & \multirow[t]{2}{*}{ Median (min-max) (\%) } & \multicolumn{2}{|l|}{$95 \% \mathrm{CI}$} & \multirow[t]{2}{*}{ p value } \\
\hline & & & Lower limit & Upper limit & \\
\hline Xanthorrhizol (0.5\%) & 6 & $70.0(13.2-76.9)$ & 33.3 & 84.5 & $0.006^{*}$ \\
\hline Xanthorrhizol $(0.75 \%)$ & 6 & $77.0(63.7-87.2)$ & 68.8 & 85.3 & \\
\hline Xanthorrhizol (1\%) & 6 & $71.6(64.1-82.6)$ & 64.8 & 79.5 & \\
\hline Xanthorrhizol (1.25\%) & 6 & $86.8(81.3-91.3)$ & 82.8 & 90.7 & \\
\hline Xanthorrhizol (1.5\%) & 6 & $83.5(71.8-87.1)$ & 74.2 & 88.4 & \\
\hline $2.5 \% \mathrm{NaOCl}$ & 6 & $86.4(0-0.103)$ & 56.0 & 90.2 & \\
\hline
\end{tabular}

*Kruskal-Wallis test with a $\mathrm{p}<0.05$

Table 2: Eradication value (\%) against the biofilm of $F$. nucleatum between xanthorrhizol at various concentrations and $2.5 \%$ NaOCl

\begin{tabular}{|c|c|c|c|c|c|c|}
\hline \multirow[t]{2}{*}{ Testing materials (concentration) } & \multicolumn{6}{|c|}{ Xanthorrhizol } \\
\hline & $0.5 \%$ & $0.75 \%$ & $1 \%$ & $1.25 \%$ & $1.5 \%$ & $2.5 \% \mathrm{NaOCl}$ \\
\hline Xanthorrhizol (0.5\%) & & 0.055 & 0.423 & $0.004^{*}$ & $0.025^{*}$ & $0.025^{*}$ \\
\hline Xanthorrhizol (0.75\%) & & & 0.297 & $0.025^{*}$ & 0.630 & 0.200 \\
\hline Xanthorrhizol (1\%) & & & & $0.006^{*}$ & $0.054 *$ & 0.078 \\
\hline Xanthorrhizol (1.25\%) & & & & & 0.149 & 0.631 \\
\hline Xanthorrhizol (1.5\%) & & & & & & 0.630 \\
\hline $2.5 \% \mathrm{NaOCl}$ & & & & & & \\
\hline
\end{tabular}

*Post hoc Mann-Whitney U test with a p<0.05

Table 3: F. nucleatum biofilm colony count (CFU/mL) after exposure to xanthorrhizol at various concentrations and 2.5\% Na0Cl

\begin{tabular}{|c|c|c|c|c|c|}
\hline \multirow[t]{2}{*}{ Treatment group (concentration) } & \multirow[t]{2}{*}{ n } & \multirow[t]{2}{*}{ Median (min-max) (CFU/mL) } & \multicolumn{2}{|l|}{$95 \% \mathrm{CI}$} & \multirow[t]{2}{*}{ p value } \\
\hline & & & Lower limit & Upper limit & \\
\hline Xanthorrhizol (0.5\%) & 6 & $1.00(0-11)$ & -1.50 & 8.50 & $0.008^{*}$ \\
\hline Xanthorrhizol $(0.75 \%)$ & 6 & $5.00(0-18)$ & -1.59 & 16.59 & \\
\hline Xanthorrhizol (1\%) & 6 & $4.00(2-9)$ & 2.32 & 8.02 & \\
\hline Xanthorrhizol (1.25\%) & 6 & $0.00(0-1)$ & -0.26 & 0.60 & \\
\hline Xanthorrhizol (1.5\%) & 6 & $0.00(0-1)$ & -0.26 & 0.60 & \\
\hline $2.5 \% \mathrm{NaOCl}$ & 6 & $0.00(0-1)$ & -0.26 & 0.60 & \\
\hline
\end{tabular}

*Kruskal-Wallis test with a $\mathrm{p}<0.05$ 
Table 4: Total count of the biofilm of $F$ nucleatum colonies on the well plate after exposure to various concentrations of xanthorrhizol and $2.5 \% \mathrm{NaOCl}$

\begin{tabular}{lllllll}
\hline Materials (concentration) & \multicolumn{2}{l}{ Xanthorrhizol } & & & & \\
\cline { 2 - 7 } & $\mathbf{0 . 5 \%}$ & $\mathbf{0 . 7 5 \%}$ & $\mathbf{1 \%}$ & $\mathbf{1 . 2 5 \%}$ & $\mathbf{1 . 5 \%}$ & $\mathbf{2 . 5 \%} \mathbf{~ N a O C l}$ \\
\hline Xanthorrhizol (0.5\%) & & 0.739 & 0.224 & 0.072 & 0.072 & 0.072 \\
Xanthorrhizol (0.75\%) & & 1.000 & 0.153 & 0.153 & 0.153 \\
Xanthorrhizol (1\%) & & & $0.003^{*}$ & $0.003^{*}$ & $0.003^{*}$ \\
Xanthorrhizol (1.25\%) & & & & 1.000 & 1.000 \\
Xanthorrhizol (1.5\%) & & & & & \\
2.5\% NaOCl & & & & & & \\
\hline
\end{tabular}

*Post hoc Mann-Whitney U test with a p $<0.05$

unpleasant smell and taste, and it may trigger allergic reactions. Moreover, it causes fibroblast cytotoxicity at concentrations greater than $0.05 \%$ [14].

Curcuma xanthorrhiza Roxb., also known as temulawak or Javanese turmeric, is widely used in medicines [25]. Xanthorrhizol, an active compound in essential oils obtained from the fractionation of Curcuma xanthorrhiza Roxb. plant, has antibacterial, antifungal, anticancer, antioxidant, and anti-inflammatory properties. In this study, xanthorrhizol, derived from the fractionation of ginger (Curcuma Xanthorrhiza Roxb.) obtained from PT Tri Rahardja (Javaplant), Surakarta, was used. The separation of active substances using the fractionation method aims to obtain more optimal antibacterial effects [26]. In addition, fractionation compounds have a more potent activity than the extract form, and fractionation techniques can optimally eliminate or separate unwanted compounds [27].

Xanthorrhizol's antibacterial effect was attributed to phenol and hydrocarbon chain mechanisms. Phenolic compounds consist of hydroxyl, which interacts with bacterial cells through an adsorption process. In this process, hydrogen bonds may change the bacterial cell membrane permeability. Phenol's penetration of the bacterial cells can cause coagulation of proteins that will lyse the bacterial cell membranes [25].

\section{CONCLUSION}

Xanthorrhizol at various concentrations $(0.5 \%, 0.75 \%, 1 \%, 1.25 \%$, and $1.5 \%$ ) has antibacterial effects against $F$. nucleatum biofilms. Moreover, the effect of xanthorrhizol at concentrations of $1.25 \%$ and $1.5 \%$ is similar to that of $2.5 \% \mathrm{NaOCl}$, which is effective in eliminating F. nucleatum biofilm.

\section{ACKNOWLEDGMENT}

The authors would like to thank the Department of Conservative Dentistry and Oral Biology Laboratory, Faculty of Dentistry, Indonesia University, for supporting this research.

\section{CONFLICTS OF INTEREST}

The authors have no conflicts of interest to declare.

\section{REFERENCES}

1. Martinho FC, Leite FR, Nóbrega LM, Endo MS, Nascimento GG, Darveau RP, et al. Comparison of Fusobacterium nucleatum and Porphyromonas gingivalis lipopolysaccharides clinically isolated from root canal infection in the induction of pro-inflammatory cytokines secretion. Braz Dent J 2016;27:202-7.

2. Lee LW, Lee YL, Hsiao SH, Lin HP. Bacteria in the apical root canals of teeth with apical periodontitis. J Formos Med Assoc 2017;116:448-56.

3. Siqueira JF, Rocas I. In: Siqueira JF editor. Treatment of endodontic infections. Quintessence; 2011. P. 97-103. Tyagi S, Tyagi P, Mishra P. Evolution of root canal sealers: An insight story. Eur J Gen Dent 2013;2:199-218.

4. Pereira RS, Rodrigues VA, Furtado WT, Gueiros S, Pereira GS, AvilaCampos MJ. Microbial analysis of root canal and periradicular lesion associated to teeth with endodontic failure. Anaerobe 2017;48:12-8.

5. Bolstad AI, Jensen HB, Bakken V. Taxonomy, biology, and periodontal aspects of Fusobacterium nucleatum. Clin Microbiol Rev 1996;9:55-71.

6. Gursoy UK, Pöllänen M, Könönen E, Uitto VJ Biofilm formation enhances the oxygen tolerance and invasiveness of Fusobacterium nucleatum in an oral mucosa culture model. J Periodontol 2010;81:1084-91.

7. Özok AR, Wu MK, Luppens SB, Wesselink PR. Comparison of growth and susceptibility to sodium hypochlorite of mono and dualspecies biofilms of Fusobacterium nucleatum and Peptostreptococcus (Micromonas) micros. J Endod 2007;33:819-22.

8. Kapatral V, Anderson I, Ivanova N, Reznik G, Los T, Lykidis A, et al. Genome sequence and analysis of the oral bacterium Fusobacterium nucleatum strain ATCC 25586. J Bacteriol 2002;184:2005-18.

9. Han YW. Fusobacterium nucleatum: A commensal-turned pathogen. Curr Opin Microbiol 2015;23:141-7.

10. Jhajharia K, Parolia A, Shetty KV, Mehta LK. Biofilm in endodontics: A review. J Int Soc Prev Commun Dent 2015;5:1-12.

11. Reis AL, Oliveira RR, Tavares WL, Saldanha TD, Farias LM, Vieira LQ, et al. Murine experimental root canal infection: Cytokine expression in response to F. nucleatum and E. faecalis. Braz Dent J 2016;27:578-83.

12. Tyagi S, Tyagi P, Mishra P. Evolution of root canal sealers: An insight story. Eur J Gen Dent 2013;2:199-218.

13. Xie Q, Johnson BR, Wenckus CS, Fayad MI, Wu CD. Efficacy of berberine, an antimicrobial plant alkaloid, as an endodontic irrigant against a mixed-culture biofilm in an in vitro tooth model. J Endod 2012;38:1114-7.

14. Al-Madi EM, Almohaimede AA, Al-Obaida MI, Awaad AS. Comparison of the antibacterial efficacy of Commiphora molmol and sodium hypochlorite as root canal irrigants against Enterococcus faecalis and Fusobacterium nucleatum. Hindawi Evid-Based Complement Alternat Med 2019;2019:6916795.

15. Anggoro D, Rezki RS, Siswarni MZ. Ekstraksi multi tahap kurkumin dari temulawak (Curcuma xanthorrhiza Roxb.) menggunakan pelarut etanol. J Tekn Kimia USU 2015;4:39-45.

16. Agwi SN, Barunawati N, Nihayati E. Pengaruh perbedaan pola tanam terhadap pertumbuhan dan hasil temulawak (Curcuma xanthorrhiza Roxb.) pada pola tanam tumpangsari dengan ubi jalar (Ipomoea batatas L.). J Produksi Tanaman 2017;5:1170-9.

17. Silalahi M. Curcuma xanthorrhiza Roxb. (Pemanfaatan dan Bioakivitasnya). JDP 2017;10:248-60.

18. Sukandar EY, Kurniati NF, Anggadiredja K, Kamil A. In vitro antibacterial activity of Kaempferia pandurata Roxb. and Curcuma xanthorrhiza Roxb. Extracts in combination with certain antibiotics against MSSA and MRSA. Int J Pharm Pharm Sci 2018;8:108-11.

19. Kim JE, Kim HE, Hwang JK, Lee HJ, Kwon HK, Kim BI. Antibacterial characteristics of Curcuma xanthorrhiza extract on Streptococcus mutans biofilm. J Microbiol 2008;46:228-32.

20. Rukayadi Y, Hwang JK. In vitro activity of xanthorrhizol against Streptococcus mutans biofilms. Lett Appl Microbiol 2006;42:400-4.

21. Prijatmoko D, Syafira NL, Lestari PE. Antibacterial activity of essential oil extracts from Curcuma xanthorrhiza Roxb. rhizomes against bacteria causing pulp necrosis. J Dentomaxillofac Sci 2018;3:144-8.

22. Quave CL, Plano LR, Pantuso T, Bennett BC. Effects of extracts from Italian medicinal plants on planktonic growth, biofilm formation and adherence of methicillin-resistant Staphylococcus aureus. J Ethnopharmacol 2008;118:418-28.

23. Dewi ZY, Nur A, Hertriani T. Efek antibakteri dan penghambatan biofilm ekstrak sereh (Cymbopogon nardus L.) terhadap Bakteri Streptococcus mutans. Maj Ked Gi Ind 2015;1:136-41. 
24. Yue W. The antibacterial effect of xanthorrhizol as an endodontic irrigant on Enterococcus faecalis. Yonsei Univ 2015;1:206-16.

25. European Medicines Agency. Assessment Report on Curcuma xanthorrhiza Roxb. (C. xanthorrhiza D. Dietrich), Rhizoma. Amsterdam, Netherlands: European Medicines Agency; 2014.
26. Oon SF, Nallappan M, Tee TT, Shohaimi S, Kassim NK, Saariwijaya MS, et al. Xanthorrhizol: A review of its pharmacological activities and anticancer properties. Cancer Cell Int 2015;15:100.

27. Diastuti H, Syah YM, Juliawaty LD, Singgih M. Antibacterial Curcuma xanthorrhiza exstract and fractions. J Math Fund Sci 2014;46:224-34. 